International Journal of Economics, Business and Accounting Research (IJEBAR)

Peer Reviewed - International Journal

Vol-4, Issue-2, 2020 (IJEBAR)

E-ISSN: 2614-1280 P-ISSN 2622-4771

https://jurnal.stie-aas.ac.id/index.php/IJEBAR

\title{
ANALYSIS OF WORK SATISFACTION, ORGANIZATIONAL COMMITMENTS, AND WORK ENGAGEMENT EFFFECT TOWARD EMPLOYEE PERFORMANCE IN SHARIA BANKS
}

\author{
Muhammad Tho'in1, Dewi Muliasari2 \\ 1, 2Institut Teknologi Bisnis AAS Indonesia \\ Email:thoinsyakira@yahoo.com
}

\begin{abstract}
The main objective of this research is to examine the effect of job satisfaction, organizational commitment, and work involvement on the performance of employees at Bank Syariah Mandiri (BSM) in Surakarta. This study uses a quantitative approach and the data used in this study are primary data sourced from questionnaires distributed to BSM employees totaling 60 questionnaires as respondents (according to the number of BSM employees in Surakarta). The sampling method in this study is to use a total sampling technique. Methods of data analysis using descriptive statistics, validity test, reliability test, multiple linear regression analysis test, $\mathrm{t}$ test, and $\mathrm{R} 2$ test. The results showed that partially job satisfaction variables, organizational commitment variables, and work engagement variables significantly influence employee performance at Bank Syariah Mandiri in Surakarta.
\end{abstract}

Keywords: job satisfaction, organizational commitment, job involvement, employee performance

\section{Introduction}

Performance is a potential that must be possessed by every employee to carry out every task and responsibility given by the organization to employees (Anitha, 2014); (Khan, et.al, 2016). With good performance, every employee can solve all the burden of the organization effectively and efficiently so that problems that occur in the organization can be resolved properly. Employee performance is the willingness of a person or group of people to do an activity and perfect it according to their responsibilities with the results as expected (Elnaga \& Imran, 2013). Thus, performance becomes the real foundation in an organization because if there is no performance then the organization's goals cannot be achieved. Performance needs to be used as an evaluation material for leaders to determine the level of performance that exists in the organization.

In general, performance is defined as one's success in carrying out a job. Employee performance is the result of work achieved by someone in carrying out the tasks assigned to him to achieve work targets. Employees can work well if they have high performance so they can produce good work. Employee performance is one of the determining factors in the success of a company or organization in achieving its goals (Tripathi \& Jha, 2018); (Elnaga \& Imran, 2014). For this reason, the performance of employees must receive the attention of company leaders, because the declining performance of employees can affect overall company performance.

Performance is a picture of the level of achievement of the implementation of a program of activities or policies in realizing the goals, objectives, vision, and mission of the organization as outlined through the strategic planning of an organization (Tadić, \& Boljević, 2015). Performance can be known and measured if an individual or group of employees already has criteria or standards of success that have been set by the organization. Therefore, if without the goals and targets set in the measurement, then the performance of a person or organizational performance may not be known if there are no benchmarks of success.

Performance is the result of quality and quantity of work achieved by an employee in carrying out their duties in accordance with the responsibilities given to him (Mangkunegara, 2005). Performance is a 


\section{International Journal of Economics, Business and Accounting Research (IJEBAR) Peer Reviewed - International Journal Vol-4, Issue-2, 2020 (IJEBAR) \\ E-ISSN: 2614-1280 P-ISSN 2622-4771 \\ https://jurnal.stie-aas.ac.id/index.php/IJEBAR}

function of motivation and ability. Employee performance is very important in the company's efforts to achieve its goals. Higher performance means an increase in efficiency, effectiveness, or higher quality of completing a series of tasks that are assigned to an employee in an organization or company.

Employee performance in general is influenced by two factors, namely internal and external factors. Internal factors are factors that come from within the employee, which includes job satisfaction and organizational commitment. While external factors are factors that come from outside the employee, which includes leadership, work safety and safety, and organizational culture. Employee performance in companies is influenced by organizational culture and employee satisfaction (Ismail, 2018).

One internal factor that can affect employee performance that needs to be considered is organizational commitment, because organizational commitment is an important behavioral dimension that can be used to assess the employee's tendency to stay as a member of the organization. Commitment is a person's identification and relevance that is relatively strong to the organization (Sapitri \& Suryalena, 2016). Employees with high organizational commitment have different attitudes compared to those who have low commitment. High organizational commitment produces work performance, low absenteeism and low employee turnover. High commitment makes individuals concerned with the fate of the organization and strives to make the organization better. With a high commitment the possibility of a decrease in performance can be avoided. Organizational commitment plays an important role in improving employee performance (Sapitri \& Suryalena, 2016).

The purpose of organizational commitment is to correct mistakes that occur so as not to occur continuously. Organizational commitment that is carried out well will be able to improve the performance and discipline of performance of employees and employees will always be responsible for the work carried out. Organizational commitment as one of the attitudes in work is defined as one's orientation towards the organization in the sense of loyalty, identification, and involvement (Meyer, 2016); (Aube, Rousseau \& Morin, 2007). In this case, the employee specifically identifies the organization and its objectives and hopes to remain a member of the organization. So, what is meant by the involvement of the task / work means identifying the organization / company that employs someone (Aube, Rousseau \& Morin, 2007). Organizational commitment is very important, so some organizations include this element as one of the conditions required to hold various positions offered in employment (Cohen, 2017). High commitment to the organization will make a person have a professional attitude and action and uphold various values that have been agreed upon in the organization.

Organizational commitment is related to work involvement. Work involvement is one of the internal factors that need to be improved for the progress of the organization so that it can produce maximum work. The above statement is supported by Yeh \& Hong (2012) which states that work involvement is a participatory process that uses all worker capacities and is designed to encourage increased commitment to the success of an organization. On the other hand, DeCareful \& Schaan (in Lambert, 2008) states that individuals with high levels of involvement will place work interests as a priority scale. Furthermore, Stoyanova \& Iliev (2017) argues that increasing work engagement can increase organizational effectiveness and productivity by involving more workers in earnest work so that workers get more meaningful and satisfying experiences.

Work engagement will increase if members in the organization face a situation that is important to discuss together. One situation that needs to be discussed together is for example the needs and personal interests that members want to achieve. If these needs can be met it will make these members more committed to the organization (Caillier, 2013). The member will realize the importance of trying and contributing to the interests of the organization. Work engagement is a form of participation in individuals to try as much as possible in order to achieve high commitment to the organization (Stoyanova \& Iliev, 2017); (Hanaysha, 2016). This is further clarified by the results of previous studies, for example research conducted by Singh \& Gupta (2015); (Mahajan, Bishop \& Scott, 2012) show that work involvement has a 


\section{International Journal of Economics, Business and Accounting Research (IJEBAR) Peer Reviewed - International Journal Vol-4, Issue-2, 2020 (IJEBAR) \\ E-ISSN: 2614-1280 P-ISSN 2622-4771 \\ https://jurnal.stie-aas.ac.id/index.php/IJEBAR}

positive and significant influence on organizational commitment meaning that increasing work involvement will increase organizational commitment.

Organizational commitment also affects job satisfaction. Job satisfaction as a pleasant emotional state as a result of someone's perception of his work, whether the job can fulfill or facilitate the achievement of the fulfillment of work values that are important to that person (Hayati, \& Caniago, 2012). This means that job satisfaction will lead to productivity, high quality, and high commitment in the organization. This means that the more individual feels satisfied with his work as a reflection of his workplace, then the individual will be more committed to his work, more motivated to be present in the organization, and try to work as well as possible, loyal, more stable, and productive so that ultimately more profitable for the organization or the company itself (Nagar, 2012). Job satisfaction for employees in the organization is an important factor in efforts to improve performance, therefore every company needs to try so that employees have high performance so that overall company performance will be high. Job satisfaction in general concerns a person's attitude regarding his work. Therefore job satisfaction will appear to be manifested in a person's behavior and performance. People who are satisfied with the job will work with high morale so that the employee's performance is high. Where this will have a direct or indirect impact on organizational effectiveness (Tarigan \& Ariani, 2015).

The opinion above, supported by several research results that have been done before, including research conducted by Fahrizal, et.al (2016) who found that there is a positive influence of (1) work involvement and job satisfaction on employee performance, (2) work engagement on employee performance, (3) job satisfaction on employee performance, and (4) job involvement on job satisfaction. Septiadi, et.al (2017) in his research showed that work involvement influences organizational commitment and performance. The results of this study support the theory that the higher a person is involved in a job, the higher the commitment and discipline in carrying out their duties.

Based on the description above, it can be concluded that if the individual is seriously involved in his work and is satisfied with his work, then the individual has high organizational commitment. Vice versa if the individual is not involved with the organization seriously and are not satisfied with their work then the individual has a low organizational commitment that is shown by negative behaviors so that it can affect the performance of the company or organization which will then adversely affect the sustainability of the company. This study treats employee performance as the dependent variable that is influenced by job satisfaction, organizational commitment and work involvement. And intends to examine how strong the influence of job satisfaction, organizational commitment and work involvement on company performance. This research was conducted at the Surakarta branch of Syariah Bank (BSM) with the intention to find out how strong the influence of employee job satisfaction, employee organizational commitment and employee work involvement on the performance of Surakarta branch BSM employees. Bank Syariah Mandiri (BSM) Surakarta branch was chosen as a place of research because the bank was founded based on a belief that banking operations based on profit sharing principles and profit margin taking can encourage economic stability. Bank Syariah Mandiri (BSM) as a bank that operates on the basis of Islamic sharia principles establishes a corporate culture that refers to the attitude of morality (noble character).

At this time, the condition of the Surakarta Syariah Bank (BSM) Surakarta branch showed a significant improvement. It still shows that there are obstacles to the implementation of objectives related to employee performance. Improved individual employee performance will encourage overall human resource performance. To face the problems it faces in the future, with the increasing competition in the Islamic banking industry in Surakarta, the Surakarta Syariah Bank (BSM) branch of Surakarta is required to manage reliable human resources, that is, those who are able to work harder in order to achieve various targets which have been set. 
International Journal of Economics, Business and Accounting Research (IJEBAR)

Peer Reviewed - International Journal

Vol-4, Issue-2, 2020 (IJEBAR)

E-ISSN: 2614-1280 P-ISSN 2622-4771

https://jurnal.stie-aas.ac.id/index.php/IJEBAR

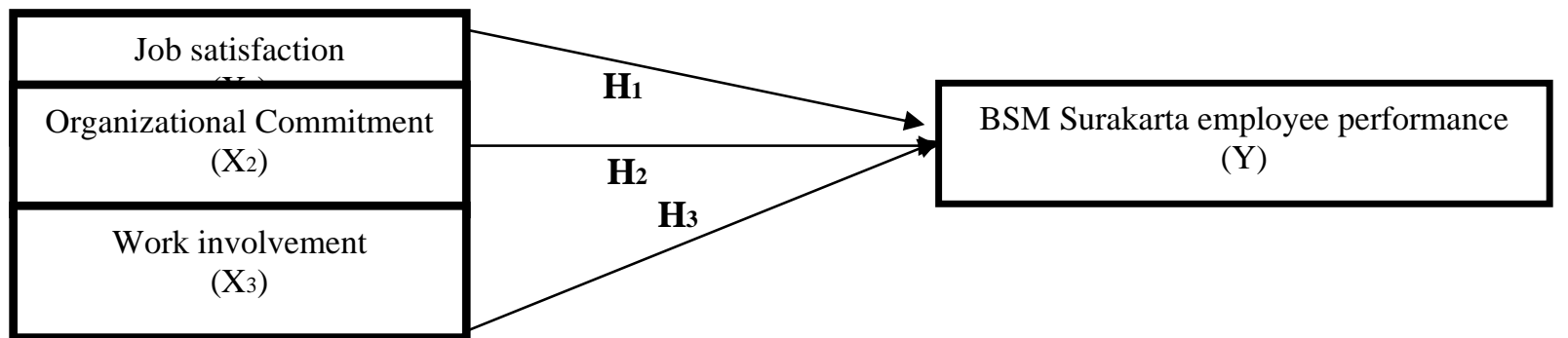

Figure 1. Theoretical Framework

\section{Research Methodology}

This study uses a quantitative approach and the data used in this study are primary data sourced from questionnaires distributed to BSM employees totaling 60 questionnaires as respondents (according to the number of BSM employees in Surakarta). The sampling method in this study is to use a total sampling technique, where the entire population is made respondent. Total sampling is a sampling technique where the number of samples is equal to the population (Sugiyono, 2011). Methods of data analysis using descriptive statistics, validity test, reliability test, multiple linear regression analysis test, $t$ test, and the coefficient of determination or $\mathrm{R}_{2}$ test.

\section{Research Results and Discussion}

\subsection{Validity Test}

Tabel 1.Validity Test

\begin{tabular}{|c|c|c|}
\hline Variable & Components & Information \\
\hline KP1 & 0,857 & Valid \\
\hline KP2 & 0,802 & Valid \\
\hline KP3 & 0,758 & Valid \\
\hline KP4 & 0,817 & Valid \\
\hline KP5 & 0,852 & Valid \\
\hline KO1 & 0,785 & Valid \\
\hline KO2 & 0,768 & Valid \\
\hline KO3 & 0,707 & Valid \\
\hline KO4 & 0,687 & Valid \\
\hline KO5 & 0,753 & Valid \\
\hline KO6 & 0,759 & Valid \\
\hline KO7 & 0,805 & Valid \\
\hline KO8 & 0,768 & Valid \\
\hline KO9 & 0,773 & Valid \\
\hline KK1 & 0,736 & Valid \\
\hline KK2 & 0,839 & Valid \\
\hline KK3 & 0,815 & Valid \\
\hline KK4 & 0,858 & Valid \\
\hline KK5 & 0,847 & Valid \\
\hline K1 & 0,777 & Valid \\
\hline K2 & 0,735 & Valid \\
\hline K3 & 0,781 & Valid \\
\hline
\end{tabular}


International Journal of Economics, Business and Accounting Research (IJEBAR)

Peer Reviewed - International Journal

Vol-4, Issue-2, 2020 (IJEBAR)

E-ISSN: 2614-1280 P-ISSN 2622-4771

https://jurnal.stie-aas.ac.id/index.php/IJEBAR

Source: primary data processed

\subsection{Reliability Test}

Tabel 2. Reliability Test Result

\begin{tabular}{|l|c|c|c|}
\hline \multicolumn{1}{|c|}{ Amount } & $\boldsymbol{R}$ count & $\boldsymbol{R}_{\text {table }}$ & Information \\
\hline Job satisfaction & 0,9305 & 0,60 & Reliable \\
\hline Organizational Commitment & 0,9233 & 0,60 & Reliable \\
\hline Work involvement & 0,9061 & 0,60 & Reliable \\
\hline Performance & 0,8616 & 0,60 & Reliable \\
\hline
\end{tabular}

Source: primary data processed

3.3. Multiple Linear Regression Analysis

Tabel 3. Results of Multiple Linear Regression Data Analysis

\begin{tabular}{|c|c|c|c|c|}
\hline Variable & $\begin{array}{l}\text { Regression } \\
\text { Coefficient }\end{array}$ & t count & t table & Significant \\
\hline Job satisfaction & 0,260 & 2,819 & 1,67 & 0,007 \\
\hline Organizational Commitment & 0,137 & 2,309 & 1,67 & 0,025 \\
\hline Work involvement & 0,236 & 2,482 & 1,67 & 0,016 \\
\hline Constant & $-2,795$ & & & \\
\hline Adj.R Square & 0,409 & & & \\
\hline $\mathrm{R}$ square & 0,439 & & & \\
\hline F count & 14,676 & & & \\
\hline
\end{tabular}

Source: primary data processed

Based on the results of the data processing test table IV.11 above, we can get the multiple linear regression equation as follows: $\mathrm{Y}=-2,795+0,260 \mathrm{X}_{1}+0,137 \mathrm{X}_{2}+0,236 \mathrm{X}_{3}$

Based on the multiple linear equations above, it can be described as follows:

a. Constant value $(-2,795)$

The negative value constant indicates that if there are no factors of job satisfaction, organizational commitment, and work involvement, then the performance will decrease. Thus it can be seen that performance is influenced by factors of job satisfaction, organizational commitment and work involvement is very strong.

b. The magnitude of the regression coefficient value of job satisfaction factor is 0.260 . This shows that there is a significant direct relationship between job satisfaction factors (X1) to performance $(\mathrm{Y})$. This means that if job satisfaction gets higher the performance will increase.

c. The magnitude of the coefficient value Regression coefficient of organizational commitment factor is 0.137. This shows that the coefficient has a significant positive effect on performance, meaning that if the organizational commitment is getting better, the performance will be better.

d. The magnitude of the regression coefficient value of artistic work engagement factors is 0.236 . This shows a positive value, namely there is a significant direct relationship between the factors of work engagement on performance variables, meaning that if work involvement is getting better the performance will increase.

\subsection{T Test}

a. Testing the influence of job satisfaction factors on performance.

At a significant level of 0.05 obtained t count of 2.819> $t$ table 1.67 then Ho is rejected. Means it can 


\section{International Journal of Economics, Business and Accounting Research (IJEBAR) \\ Peer Reviewed - International Journal \\ Vol-4, Issue-2, 2020 (IJEBAR) \\ E-ISSN: 2614-1280 P-ISSN 2622-4771 \\ https://jurnal.stie-aas.ac.id/index.php/IJEBAR}

be concluded that there is a significant influence between the factors of job satisfaction $\left(\mathrm{X}_{1}\right)$ on the performance of BSM employees in Surakarta.

b. Testing the influence of organizational commitment factors on performance

At a significant level of 0.05 obtained t count of 2.309> t table 1.67 then Ho is rejected. Means it can be concluded that there is a significant influence between the organizational commitment factor $\left(\mathrm{X}_{2}\right)$ on the performance of BSM employees in Surakarta.

c. Testing the effect of work engagement factors on performance.

At a significant level of 0.05 obtained $t$ count of 2.482>t table 1.67 then Ho is rejected. Means it can be concluded that there is a significant influence between work engagement factors $\left(\mathrm{X}_{3}\right)$ on the performance of BSM employees in Surakarta.

\subsection{Determination Coefficient Test}

Table 4. Determination Coefficient Test Results $\left(\mathrm{R}^{2}\right)$

Model Summaryb

\begin{tabular}{|l|r|r|r|r|r|}
\hline Model & R & \multicolumn{1}{|c|}{ R Square } & \multicolumn{1}{c|}{$\begin{array}{c}\text { Adjusted R } \\
\text { Square }\end{array}$} & $\begin{array}{c}\text { Std. Error of the } \\
\text { Estimate }\end{array}$ & Durbin-Watson \\
\hline 1 & ,976a &, 952 &, 950 &, 608 &, 639 \\
\hline
\end{tabular}

a. Predictors: (Constant), job satisfaction, organizational commitment, work involvement

b. Dependent Variable: performance

The test results show the influence of variables $\mathrm{X} 1, \mathrm{X} 2$, and $\mathrm{X} 3$. Based on testing the $\mathrm{R}^{2}$ value of 0.950 was obtained. Thus, the independent variable consisting of three namely job satisfaction, organizational commitment, and work involvement affect the performance of Bank Syariah Mandiri employees in Surakarta by $95 \%$, while the remaining $5 \%$ BSM employee performance is influenced by other factors or variables.

\section{Conclusion}

From the research results obtained it can be concluded that there is a significant influence between job satisfaction factors on employee performance at Bank Syariah Mandiri in Surakarta. There is a significant influence between organizational commitment factors on employee performance at Bank Syariah Mandiri in Surakarta. There is a significant influence between work engagement factors on employee performance at Bank Syariah Mandiri in Surakarta.

\section{Acknowledgement}

We thank the Institute of ITB AAS Indonesia, Head of the Central Java Center for Education and Education Studies (Puskape) Dr. Sri Lahir, and various parties who helped smooth the research activities.

\section{References}

Anitha, J. (2014). Determinants of employee engagement and their impact on employee performance. International journal of productivity and performance management.

Aube, C., Rousseau, V., \& Morin, E. M. (2007). Perceived organizational support and organizational commitment. Journal of managerial Psychology.

Caillier, J. G. (2013). Satisfaction with work-life benefits and organizational commitment/job involvement: Is there a connection?. Review of Public Personnel Administration, 33(4), 340-364.

Cohen, A. (2017). Organizational Commitment and Turnover: A Met A-Analysis. Academy of management journal. 
International Journal of Economics, Business and Accounting Research (IJEBAR)

Peer Reviewed - International Journal

Vol-4, Issue-2, 2020 (IJEBAR)

E-ISSN: 2614-1280 P-ISSN 2622-4771

https://jurnal.stie-aas.ac.id/index.php/IJEBAR

Elnaga, A., \& Imran, A. (2013). The effect of training on employee performance. European journal of Business and Management, 5(4), 137-147.

Elnaga, A. A., \& Imran, A. (2014). The impact of employee empowerment on job satisfaction: theoretical study. American Journal of Research Communication, 2(1), 13-26.

Fahrizal, V., Bagia, I. W., Si, M., Susila, G. P. A. J., \& SE, M. (2016). Pengaruh Keterlibatan Kerja dan Kepuasan Kerja Terhadap Kinerja Karyawan Pada Hotel Banyualit Resort and Spa Lovina Tahun 2016. Jurnal Jurusan Manajemen, 5(2).

Hanaysha, J. (2016). Testing the effects of employee engagement, work environment, and organizational learning on organizational commitment. Procedia-Social and Behavioral Sciences, 229(8), 289-297.

Hayati, K., \& Caniago, I. (2012). Islamic work ethic: The role of intrinsic motivation, job satisfaction, organizational commitment and job performance. Procedia-Social and Behavioral Sciences, 65, 1102-1106.

Ismail, I. (2018). Pengaruh Budaya Organisasi terhadap Kepemimpinan dan Kinerja Karyawan Pemerintah Kabupaten-kabupaten di Madura. EKUITAS (Jurnal Ekonomi dan Keuangan), 12(1), 1836.

Khan, A. A., Abbasi, S. O. B. H., Waseem, R. M., Ayaz, M., \& Ijaz, M. (2016). Impact of training and development of employees on employee performance through job satisfaction: A study of telecom sector of Pakistan. Business Management and Strategy, 7(1), 29-46.

Mahajan, A., Bishop, J. W., \& Scott, D. (2012). Does trust in top management mediate top management communication, employee involvement and organizational commitment relationships?. Journal of Managerial Issues, 173-190.

Mangkunegara, A. P. (2005). Evaluasi Kinerja SDM: Refika Aditama Bandung.

Meyer, J. P. (2016). Commitment. In Encyclopedia of Human Resource Management. Edward Elgar Publishing Limited.

Nagar, K. (2012). Organizational commitment and job satisfaction among teachers during times of burnout. Vikalpa, 37(2), 43-60.

Sapitri, R., \& Suryalena, S. (2016). Pengaruh komitmen organisasi terhadap kinerja karyawan Perusahaan Listrik Negara area Pekanbaru (Doctoral dissertation, Riau University).

Septiadi, S. A., Sintaasih, D. K., \& Wibawa, I. M. A. (2017). Pengaruh keterlibatan kerja terhadap kinerja dengan pemediasi komitmen organisasional. E-Jurnal Ekonomi dan Bisnis Universitas Udayana, 3103-3132.

Singh, A., \& Gupta, B. (2015). Job involvement, organizational commitment, professional commitment, and team commitment. Benchmarking: An International Journal.

Stoyanova, T., \& Iliev, I. (2017). Employee engagement factor for organizational excellence. International Journal of Business and Economic Sciences Applied Research (IJBESAR), 10(1), 23-29.

Sugiyono, P. (2011). Metodologi penelitian kuantitatif kualitatif dan R\&D. Alpabeta, Bandung.

Tadić, J., \& Boljević, A. (2015). Integration of critical success factors in order to improve performance of the company. Strategic Management, 20(1), 26-33.

Tarigan, V., \& Ariani, DW. (2015). Empirical study relations job satisfaction, organizational commitment, \& turnover intention. Advances in Management and Applied Economics, 5(2), 21.

Tripathi, K. K., \& Jha, K. N. (2018). Determining success factors for a construction organization: A structural equation modeling approach. Journal of management in engineering, 34(1), 04017050.

Yeh, H., \& Hong, D. (2012). The mediating effect of organizational commitment on leadership type and job performance. The Journal of Human Resource and Adult Learning, 8(2), 50. 